\title{
Akmal_Fakhlevi_PIK.docx by
}

Submission date: 01-Jan-2022 06:34PM (UTC+0700)

Submission ID: 1736741994

File name: Akmal_Fakhlevi_PIK.docx (75.91K)

Word count: 3067

Character count: 19419 


\title{
ANALISIS BAHASA PEMROGRAMAN KOMPUTER C++ DALAM SISTEM INFORMASI MANAJEMEN
}

\author{
AKMAL FAKHLEVI (0702212196) \\ SISTEM INFORMASI - 6
}

Akmalfakhlevi04@gmail.com

\begin{abstract}
Abstrak
Artikel ini merupakan hasil pembelajaran bahasa pemrograman $\mathrm{C}++$. Artikel pembelejaran ini adalah artikel yang diandalkan untuk membantu pembaca dalam memahami ide dan isi dalam bahasa pemrograman $\mathrm{C}++$. Artikel ini dapat dimanfaatkan menjadi pilihan unutk belajar mandiri bagi pembaca. Materi yang dibahas dalam artikel ini adalah latar belakang sejarah pembuatan $\mathrm{C}++$,Pengertian $\mathrm{C}++$,Defenisi dari $\mathrm{C}++$, struktur program, komponen-komponen penting pemrograman dalam bahasa $\mathrm{C}++$. Artikel pembelajaran ini dibuat dengan cara prototyping worldview dengan perangkat pendukung seperti Adobe Streak CS3, Microsoft Word 2010, Adobe Photosop CS3. Produk akhir dari kemajuan Artikel ini adalah sebuag disc cerdas, yang target pembacanya adalah mahasiswa yang ingin menguasai Bahasa Pemrograman $\mathrm{C}++$.

Kata-kata kunci: bahasa pemrograman, bahasa pemrograman $\mathrm{C}++$, media pembelajaran.
\end{abstract}




\section{ENDAHULUAN}

Dengan banyaknya dialek pemrograman yang tersedia saat ini, seperti $\mathrm{C}, \mathrm{C}++$, Python, Perl, Java, dan Ruby yang digunakan oleh organisasi, dialek pemrograman dinamis menjadi yang paling penting bagi organisasi. pengembang. melakukan latihan mereka. Arti penting dari artikel bahasa pemrograman terletak sebagai metode untuk membuat aplikasi yang akan dibuat sebagai: namun juga keuntungan positif bagi daerah sebagai klien. Akibatnya, bahasa pemrograman harus memiliki produktivitas bahasa pemrograman yang layak pada akhirnya, terutama dalam hal kemampuan pengkodean. Selanjutnya pada artikel kali ini saya akan mengulas tentang bahasa pemrograman $\mathrm{C}++$ yang ditunjukkan dengan mata kuliah yang saya jalani. Bahasa yang merupakan sejenis bahasa $\mathrm{C}$, namun berbeda dari bahasa $\mathrm{C}$ dalam pemrograman. $\mathrm{C}++$ adalah bahasa pemrograman yang bekerja dengan objek atau bisa disebut sebagai Protes Arrangement Programming (OOP). [1]

Dalam merumuskan masalah di sini, kurang lebih dijelaskan

1. Sejarah bahasa $\mathrm{C}++$ ?

2. Apa itu $\mathrm{C}++$ ?

3. Jenis Fungsi $\mathrm{C}++$ ?

4. Macam Macam Tipe Data dalam $\mathrm{C}++$ ?

5. Input dan Output dalam $\mathrm{C}++$

Kegiatan ini dimaksudkan agar dapat bermanfaat dan memberikan informasi bagi mahasiswa yang ingin mempelajari lebih dalam tentang bahasa pemrograman $\mathrm{C}++$.

Peneliti akan menggunakan hasil penelitian ini untuk menilai kemampuan menerapkan teori pem- rograman dalam bahasa $\mathrm{C}++$ dan memberikan informasi tentang pemrograman $\mathrm{C}++$.

Metode persiapan terdiri dari mempelajari buku dan referensi tentang bahasa pemrograman $\mathrm{C}++$. Peran bahasa pemrograman dalam membuat aplikasi sangat penting. Oleh karena itu, bahasa pemrograman merupakan instruksi untuk mengendalikan komputer yang menghubungkan programmer dengan aplikasi yang akan dibuat atau dijalankan.

\section{TINJAUAN_PUSTAKA}

\section{Memahami bahasa pemrograman}

Bahasa pemrograman adalah petunjuk standar yang digunakan untuk mengajarkan PC memainkan kapasitas tertentu. Bahasa ini memungkinkan untuk mencirikan dengan tepat informasi apa yang diproses PC, bagaimana informasi ini disimpan atau dikomunikasikan, dan langkah apa yang harus diambil dalam berbagai keadaan. Kapasitas bahasa pemrograman adalah untuk menyarankan PC untuk menangani informasi seperti yang ditunjukkan oleh garis pemikiran yang ideal. Hasil dari sebuah bahasa pemrograman adalah program atau aplikasi.

Bahasa pemrograman, atau sering disebut coding atau kode Bahasa pemrograman $\mathrm{PC}$, adalah petunjuk standar untuk mengelola PC. Bahasa Program komputer penulisan ini adalah sekumpulan standar tata bahasa dan semantik yang digunakan untuk mengkarakterisasi program PC. Bahasa ini memungkinkan seorang insinyur perangkat lunak dapat memutuskan secara tepat informasi mana yang akan ditangani oleh PC, bagaimana informasi tersebut ini akan disimpan/dikirim, dan 
langkah-langkah seperti apa yang akan diambil keadaan yang berbeda. Bahasa pemrograman (programming language) merupakan pedoman standar untuk memerintahkan PC untuk mengisi peran tertentu. Bahasa pemrograman ini adalah sekelompok prinsip sintaksis dan semantik yang digunakan untuk mengkarakterisasi program komputer. Bahasa ini memungkinkan seorang insinyur perangkat lunak untuk memutuskan dengan tegas informasi apa yang akan ditangani oleh PC, bagaimana informasi ini akan disimpan/dikirim, dan tepatnya langkah-langkah apa yang harus diambil dalam situasi yang berbeda. [2]

Bahasa pemrograman yang kita kenal menggabungkan Essential Compiler (BASCOM), Java, Visual Fundamental, C++, C, Cobol, PHP, Net, dan banyak dialek yang berbeda. Tentunya prasyarat bahasa ini harus disesuaikan dengan kapasitas dan gadget yang menggunakannya. Pada umumnya, dialek pemrograman diisolasi menjadi 4 kelompok, khususnya::

- Bahasa berorientasi objek (Visual dBase, Visual FoxPro, Delphi, Visual C)

- Bahasa tingkat tinggi (seperti Pascal dan Basic)

- Bahasa tingkat menengah (sebagai C) dan

- Bahasa tingkat rendah (sebagai assembler)

\section{Definisi bahasa pemrograman $\mathrm{C}++$}

Basis bahasa $\mathrm{C}$ adalah bahasa BCPL, yang diciptakan pada tahun 1967 oleh Martin Richards. Bentuk-bentuk tertentu dari bahasa $\mathrm{C}$ berkumpul dengan adaptasi yang berbeda dari bahasa $\mathrm{C}$ dengan sedikit perubahan.

Bahasa $\mathrm{C}$ dan $\mathrm{C}++$ adalah bahasa yang sangat terkenal di jagad kemajuan program. Kedua dialek ini dinamakan dialek tingkat sedang. Sejak pergantian peristiwa, dialek $\mathrm{C}$ dan $\mathrm{C}++$ telah banyak digunakan untuk membina program aplikasi dalam kerangka kerja dan komunikasi siaran di dunia moneter atau bisnis. Memang, bahkan saat ini, sebagian besar pemrograman game (game) PC menggunakan bahasa $\mathrm{C}$ atau $\mathrm{C}++$.

Berbagai alasan mengapa bahasa $\mathrm{C} / \mathrm{C}++$ banyak digunakan, antara lain sebagai berikut:

1) Bahasa $C$ tersedia di hampir semua jenis komputer

2) Kode bahasa $\mathrm{C}$ bersifat portable. Aplikasi yang ditulis dalam bahasa $\mathrm{C}$ untuk satu komputer dapat digunakan di komputer lain dengan hanya sedikit perubahan

3) Bahasa $\mathrm{C}$ memiliki beberapa kata kunci

4) Proses eksekusi program $\mathrm{C}++$ lebih cepat

5) Mendukung banyak perpustakaan.

Keandalan bahasa $\mathrm{C}$ dan $\mathrm{C}++$ dicapai melalui keberadaan fungsi perpustakaan.

Computer berasal dari kata to process yang artinya menghitung. Menurut VC Hamacher, ZG Vranesic dan SG Zaky yang merupakan individu dari Organisasi Komputer, PC dicirikan sebagai mesin kerja elektronik yang dapat dengan cepat mendapatkan data info lanjutan, memprosesnya sesuai program yang disimpan dalam memorinya (disimpan program) dan menghasilkan data hasil. Computer terbuat dari bagian yang dinormalisasi, termasuk bagian tambahan dan kartu pengembangan untuk mengisi peran tertentu pada Com- 
puter. Alasan kerangka kerja Computer adalah untuk menangani informasi untuk mengirimkan data. Agar tujuan prinsip ini dapat diakui, harus ada komponen yang membantunya. Komponenkomponen tersebut adalah produk pikiran (manusia), (peralatan) dan (pemrograman). Tiga komponen kerangka kerja PC harus saling berhubungan dan membentuk unit tersendiri. Peralatan tanpa pemrograman, itu tidak akan bekerja dengan benar ke bentuk, hanya hal-hal yang tidak bernyawa. Produk yang akan bekerja peralatan. [3]

Manajemen Informasi Sistem (MIS) adalah kerangka kerja yang berputar dan memilah-milah informasi dan data yang berguna untuk membantu pelaksanaan tugas di dalam suatu asosiasi. Manajemen Informasi Sistem atau MIS (bahasa Inggris: the executives data framework, MIS) adalah kerangka kerja yang mengatur bagian dari pengendalian internal suatu bisnis yang menggabungkan pemanfaatan individu, arsip, inovasi, dan sistem oleh pembukuan eksekutif untuk mengurus bisnis. masalah seperti pengeluaran. item, administrasi, atau prosedur bisnis. Kerangka kerja data dewan dikenali dari kerangka data umum karena MIS digunakan untuk memecah kerangka kerja data lain yang diterapkan pada latihan fungsional asosiasi. Secara skolastik, istilah ini sebagian besar digunakan untuk merujuk pada pengumpulan data, strategi dewan yang terkait dengan komputerisasi atau dukungan arahan manusia, misalnya, jaringan pendukung emosional pilihan, kerangka kerja utama, dan kerangka kerja data pemimpin. [4]

\section{ISI DAN PEMBAHASAN}

\section{Sejarah C++}

Pada tahun 1978, Brian W. Kerninghan dan Nook nis M. Ritchie dari fasilitas AT\&T Research membentuk bahasa B menjadi bahasa B C. Ken Thompson benar-benar merupakan peningkatan lebih lanjut dari bahasa BCPL (Joined Essential Programming Language) Martin Richard.

Mulai sekitar tahun 1980 , bahasa C secara umum digunakan dalam pemrograman di Eropa, di mana dialek B dan BCPL baru-baru ini digunakan. Dalam pergantian peristiwanya, bahasa $\mathrm{C}$ berubah menjadi bahasa yang paling terkenal di antara dialek yang berbeda seperti PASCAL, Fundamental, FORTRAN.

Pada tahun 1989, dunia pemrograman C melihat pencapaian yang signifikan dengan distribusi standar bahasa $\mathrm{C}$ oleh American Public Guidelines Establishment (ANSI). Bahasa C yang dibuat oleh Kerninghan dan Ritchie kemudian disebut sebagai peningkatan ANSI C yang dikenal sebagai $\mathrm{C}++$. Sejujurnya, bahasa $\mathrm{C}++$ melewati dua fase pengembangan. $\mathrm{C}++$ utama yang didistribusikan oleh AT\&T Labs disebut cfront. Adaptasi lama dari $\mathrm{C}++$ ini hanya compiler yang membuat interpretasi dari $\mathrm{C}++\mathrm{ke} \mathrm{C}$

Kompiler yang dapat mengubah $\mathrm{C}++$ secara langsung ke bahasa mesin (agen konstruksi). Sejak peningkatannya pada tahun 1990, C++ telah berkembang menjadi bahasa yang diatur item yang digunakan oleh sebagian besar pengembang ahli. [5]

\section{Pengertian $\mathrm{C}++$}


$\mathrm{C}++$ adalah bahasa pemrograman multi-regional, sangat mirip dengan bahasa individu yang memiliki banyak bahasa daerah. Dalam $\underset{1}{\mathrm{C}++}$, istilah tersebut bukan karena penuturnya berasal dari Jepang atau Indonesia, tetapi karena dialeknya memiliki beberana unsur unik. Ada empat kompiler terkenal: Borland $\mathrm{C}++$, Microsoft Visual $\mathrm{C}++$, Watcom C/386, dan DJGPP. Setiap kompiler ini agak unik. Kompilator mana pun dapat melakukan kapasitas C++ ANSI/ISO standar, namun kompiler mana pun juga dapat melakukan kapasitas non-standar (kapasitas ini seperti dialek non-standar yang digunakan oleh individu di berbagai bagian negara. Misalnya, New Orleans menggunakan Kata Tengah se dikenal sebagai yayasan nonpartisan). Terkadang penggunaan kapasitas non-standar membuat masalah ketika Anda perlu memesan kode sumber (yaitu, program $\mathrm{C}++$ yang dibuat oleh pengembang) dengan kompiler lain. Latihan instruksional ini secara tegas terkait dengan masalah ini, Manfaat bahasa $\mathrm{C}++$ adalah dapat diakses secara praktis di berbagai PC. Proyek $\mathrm{C}+=$ dapat disusun dengan alat konten apa pun seperti Scratch pad atau dengan manajer editorial implisit kompiler. Program $\mathrm{C}++$ sebagian besar terdiri dari ekspansi .CPP. Untuk menjalankan program ini, awalnya harus diatur dengan compiler $\mathrm{C}++$.

Pada waktu penyusunan, program sumber (.CPP) beserta dokumen header (dengan perluasan $\mathrm{H}$ atau .HPP) diubah menjadi kode objek (.OBJ) oleh compiler $\mathrm{C}++$. Dokumen artikel ini adalah catatan organisasi ganda (0 dan 1 dikodekan).

Dokumen-dokumen artikel ini juga terhubung dengan catatan item lain dan catatan perpustakaan (.LIB) menggunakan linker. Hasilnya adalah dokumen yang dapat dieksekusi. Dokumen ini dapat langsung dieksekusi oleh kerangka kerja.

Program C++ berjalan lebih cepat. Hal ini dikarenakan compiler $\mathrm{C}++$ yang cukup kecil, sehingga PC tidak perlu mencoba untuk menjalankannya. $\mathrm{C}++$ memberikan hasil yang lebih cepat dalam proses konfirmasi program daripada proyek yang berbeda. $\mathrm{C}++$ adalah bahasa yang terorganisir dan dengan cara ini mendukung lebih banyak pemrograman berbasis item.

14 Karena $\mathrm{C}++$ akan lebih mudah dipelajari dan dipahami mengingat sifatnya yang lebih terukur, yang mengatur ulang dan mencirikan kapasitas dan faktor sebagai item

Kekurangan $\mathrm{C}++$ adalah bahasanya sangat sulit dipelajari dan dipahami. Kekayaan kemampuan beradaptasi administrator yang tercatat sebagai program hard copy di sana-sini membingungkan klien.. [6]

\section{Fungsi C++}

Fungsi adalah sekumpulan arah kerja program yang dapat mengakui pertentangan masukan dan mengembalikan hasil hasil, yang dapat berupa nilai atau akibat dari kegiatan.

Nama kerja yang dikarakterisasi sendiri oleh insinyur perangkat lunak tidak dapat dibedakan dari nama kapasitas implisit dalam kompiler $\mathrm{C}++$. Kapasitas digunakan sehingga pengembang dapat mencoba untuk tidak membuat bagian dari program (kode) lebih dari sekali, menyusun kode program lebih jelas, dan membuatnya lebih mudah untuk menyelidiki program. Program ini menggabungkan banyak kapasitas untuk mengurangi penyandian salinan dan membuatnya lebih jelas. 
Pada dasarnya, ada kapasitas yang tidak mengambil batas tunggal dan mengembalikan kekosongan (informasi tanpa kualitas). Meskipun demikian, kapasitas yang berbeda mengambil batas dan dapat mengembalikan kualitas tertentu. [7]

Judul dan Fundamental()

Beberapa bagian yang perlu dipertimbangkan adalah judul dan kapasitas. Di header kita mengingat library $\mathrm{C}++$ untuk kode program kita. Kapasitas adalah "tempat" di mana kita dapat "menganalisis". Ini berisi semua pernyataan yang dibuat oleh kami. Program yang paling tidak sulit yang diketahui manusia adalah:

// Program C ++ pertama saya

\#include

int main ()

\{

cout \& 1t; \& 1t; "Halo Dunia!";

kembali 0 ;

\}

Satu per satu:

/Program $\mathrm{C}++$ pertama saya

2 Baris ini adalah komentar. Semua baris yang dimulai dengan 2 potongan (//) diperlakukan sebagai komentar dan tidak berdampak pada program. Ini sangat baik dapat digunakan oleh para insinyur perangkat lunak untuk menambahkan klarifikasi atau persepsi singkat ke program.[8]

\section{\#include}

Kalimat yang diawali dengan person (\#) adalah perintah preprocessor. Ini bukan baris kode yang dieksekusi, namun catatan untuk kompiler. Untuk situasi ini, setel \#include melatih praprosesor kompiler untuk memasukkan header dari dokumen iostream default. Dokumen khusus ini juga berisi pustaka presentasi $\mathrm{C}++_{2} \mathrm{I} / \mathrm{O}$ standar dan disertakan karena kegunaannya akan digunakan nanti dalam program.

int utama()

Baris ini dibandingkan dengan awal dari penegasan kapasitas fundamental. Kapasitas utama adalah tahap awal dari mana semua program $\mathrm{C}++$ dijalankan. Ditetapkan menjelang awal, tengah, atau akhir program, substansi kapasitas fundamental selalu dijalankan terlebih dahulu. Pada dasarnya semua program $\mathrm{C}++$ memiliki satu prinsip kerja.

Prinsip diikuti oleh beberapa tanda kurung () karena itu adalah kapasitas. Di $\mathrm{C}++$, semua kapasitas diikuti oleh beberapa lampiran (), yang dapat berisi pertentangan. Ini diikuti oleh substansi kapasitas utama sebagai pernyataan yang tepat dan terbungkus dalam dukungan bergelombang $(\{\})$

<i> \&lt; "Halo dunia!";

Petunjuk ini adalah bagian utama dari contoh program. Cout adalah aliran hasil standar di $\mathrm{C}++$ (umumnya layar). Cout diproklamirkan di header dokumen iostream.h, jadi harus dimasukkan untuk menggunakan catatan ini.

Setiap kalimat ditutup dengan titik koma (;). Orang ini menunjukkan akhir dari pernyataan dan harus diingat menjelang akhir setiap pernyataan untuk setiap program $\mathrm{C}++$.

membawa 0 kembali;

Artikulasi kembali menyebabkan kapasitas principle() untuk keluar dan mengembalikan kode setelah pernyataan ini, untuk situasi ini 0 . Ini ada- 
lah teknik yang paling umum digunakan untuk keluar dari program.[9]

\section{Komentar}

Keterangan penting untuk program yang diabaikan oleh kompiler. Jangan bergerak. Mereka sangat membantu bagi pengembang untuk memasukkan catatan tambahan atau penggambaran tentang program. $\mathrm{C}++$ memiliki dua cara berbeda untuk merekam komentar:

\section{// Komentar baris}

\section{/ * Blokir komentar}

*/

Komentar baris mengabaikan semuanya dari (//) hingga akhir baris yang sama. Blokir komentar abaikan apa pun di antara penanda

/ * dan */.

Basic Memasukkan file input dan output di C++ \#include

/ \#include "stdio.h"

Stdio $=$ Input standar Output

Untuk menjalankan fungsi input dan cetak

Input: scanf

Cetak: printf

\#include

/ \# include "iostream .h"

Iostream = Input Output Stream

Untuk menjalankan fungsi input dan cetak

Input: cin

Output: cout

\#include

/ \#include "conio.h" [10]

\section{Conio $=$ Console Input Output}

Untuk menjalankan getch dan fungsi clrscr

Getch: untuk menjaga layar

\section{Macam- Macam Tipe Data C++}

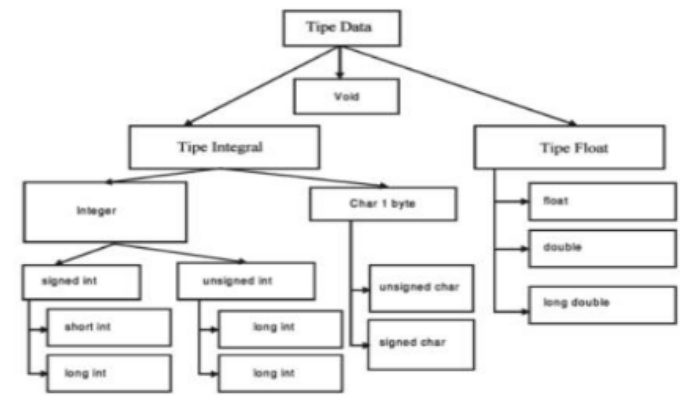

Gambar 1 .

Tipe Bilangan Bulat

\begin{tabular}{|l|l|l|}
\hline \multicolumn{1}{|c|}{ Tipe Data } & \multicolumn{1}{|c|}{ Ukuran } & \multicolumn{1}{c|}{ Range } \\
\hline int & 16 atau 32 & -32.767 s/d 32.767 \\
\hline $\begin{array}{l}\text { Signed int } \\
\text { Short int }\end{array}$ & 16 atau 32 & Sama dengan int \\
\hline Long int & 32 & Sama dengan int \\
\hline $\begin{array}{l}\text { Unsigned } \\
\text { int } 11\end{array}$ & 16 atau32 & 0 s/d 65.535 \\
\hline Short int & 16 & 0 s/d 65.535 \\
\hline Long int & 32 & 0 s/d 4.294.967.295 \\
\hline
\end{tabular}

Tipe Bilangan Desimal

\begin{tabular}{|l|l|l|}
\hline \multicolumn{1}{|c|}{ Tipe Data } & \multicolumn{1}{c|}{ Ukuran } & \multicolumn{1}{c|}{ Range } \\
\hline Float & 32 & 6 digit presisi \\
\hline Double & 64 & 10 digit presisi \\
\hline $\begin{array}{l}\text { Long Dou- } \\
\text { ble }\end{array}$ & 80 & 10 digit presisi \\
\hline
\end{tabular}

Tipe Karakter/String

\begin{tabular}{|l|l|l|}
\hline \multicolumn{1}{|c|}{ Tipe Data } & \multicolumn{1}{c|}{ Ukuran } & \multicolumn{1}{c|}{ Range } \\
\hline Char & 8 & -127 s/d 127 \\
\hline Unsigned & 8 & 0 s/d 255 \\
\hline
\end{tabular}




\begin{tabular}{|l|l|l|}
\hline char & & \\
\hline Signed char & 8 & -127 s/d 127 \\
\hline
\end{tabular}

[11]

\section{Masukan (input) dan keluaran (output) pada C++ \\ 1) Masukan (input ke) $\mathrm{C}++$}

Beberapa info pesanan yang bisa dimanfaatkan:

- Scanf

- Holt

- Cin

- Getch

- Getche

a) Scanf

Digunakan untuk jenis yang berbeda. masukkan informasi menggunakan konsol.

b) Get

Digunakan untuk mendapatkan dan me masukkan informasi string. Struktur ka limat:

Gets(nama cluster variabel);

\section{c) Cin}

Dalam $\mathrm{C}++$, perintah cin digunakan untuk memasukkan nilai dari perangkat informasi (konsol) untuk penanganan tambahan oleh program. Struktur kalimatnya adalah:

Cin $>>$ variabel; [13]

d) Getch

Perintah getch() bekerja sama seperti cin (urutan input), namun getch() direncanakan secara eksplisit untuk memasukkan karakter. Selain itu, getch() dapat membaca dengan teliti input sebagai spasi atau tab, sedangkan cin tidak. Kapasitas ini juga dapat dimanfaatkan

Variabel $=$ getch();

e) Getche

Perintah getche() berfungsi setara dengan getch(), sekali lagi, sebenarnya getche() menunjuk- kan/membaca dengan teliti karakter yang dimasukkan, tidak perlu menekan tombol Enter, dan menampilkan karakter yang dimasukkan di layar. Kapasitas getch() dan getche() memerlukan catatan header conio.h [14]

\section{2) Keluaran dalam $\mathrm{C}++$}

Beberapa result order yang dapat dimanfaatkan:

- Printf

- Puts

- Putchar

- Cout

- Cprintf

a) Printf

digunakan untuk menunjukkan hasil yang terorganisir dengan menggunakan pengaturan tertentu.

b) Puts

Digunakan untuk membuat string karakter di layar di mana pencetakan ditutup dengan ${ }_{1}$ jeda baris (di baris lain). Itu terletak di dokumen header stdio.h.

c) Putchar

Menampilkan karakter di layar, pencetakan karakter tidak diakhiri dengan jeda baris, terdapat pada dokumen header: stdio.h [15]

d) Cout

Dalam C++ perintah cout digunakan untuk mengirim data ke gadget hasil (tampilan). Berikutnya adalah pesanan tambahan untuk mendesain layar hasil. endl Perintah ini berfungsi setara dengan (Ubah baris) setw() Dengan urutan ini Anda mengatur lebar tampilan informasi (dipertahankan dengan benar). setfill() Perintah setfill() digunakan untuk menambahkan karakter tertentu ke bagian yang kosong dalam informasi.

Perintah tambahan di cout di atas memerlukan pemanfaatan catatan header iomanip.h.

e) Cprintf 
Memiliki kapasitas seperti printf, hanya cprintf yang dapat menampilkan tone dan juga terdapat pada dokumen header stdio.h. [16]

\section{Kesimpulan dan Saran \\ Bahasa Pemrograman C++}

$\mathrm{C}++$ dan $\mathrm{C}$ menyerupai arketipe mereka, $\mathrm{C}$ adalah bahasa pemrograman tingkat menengah. Pembuat C adalah Brian W. Kerninghan dan Denni W. Ritchie pada tahun 1972. C adalah bahasa pemrograman terorganisir yang mempartisi program menjadi blok-blok (subrutin). Motivasinya adalah untuk bekerja dengan pembuatan dan peningkatan program. Proyek yang ditulis dalam $\mathrm{C}$ dapat dengan mudah dipindahkan mulai dari satu mesin lalu ke mesin berikutnya. Hal ini dikarenakan normalisasi C, khususnya ANSI (American Public Principles Organization) yang menjadi acuan para pembuatnya, yang dilakukan 10 tahun setelah C.C++ dibuat pada tahun 1983 oleh Bjarne Stroustroup dari Ringer Research center, AT\&T. C++ utama bernama "A Superior C". Nama C++ sendiri diberikan oleh Rick Mascitti. Karakter ++ berasal dari administrator augmentasi di C

Kekuatan $\mathrm{C}++$ adalah ia menjunjung tinggi OOP (Article Sulated Programming). Tujuan utama $\mathrm{C}++$ adalah untuk memperluas efisiensi pemrograman saat membangun aplikasi. Kebanyakan spesialis setuju bahwa OOP dan $\mathrm{C}++$ dapat mengurangi kerumitan, terutama untuk program yang lebih panjang dari 10.000 baris, dan bahkan dapat melipatgandakan efisiensi C, Pascal, dan Essential.

Proyek C++
Proyek C++ dapat ditulis di manajer mana pun atau di kompiler dengan alat konten apa pun. Program prinsip memiliki postfix (.CPP). Saat menggabungkan, program utama dan dokumen header (.h) dibuat interpretasi oleh kompilator untuk memprotes catatan (.OBJ). Dokumen item ini kemudian dihubungkan ke catatan artikel lain dan dokumen perpustakaan (.LIB) menggunakan linker. Hasilnya adalah dan \# 40; .EXE dan \# 41; dapat dieksekusi.

Kompiler C++

Kompiler $\mathrm{C}++$ yang tersedia menggabungkan Microsoft $\mathrm{C} / \mathrm{C}++$ dan Visual $\mathrm{C}++$. Keduanya dari Microsoft. Sementara itu, Borland Worldwide juga telah menghadirkan Super C++ dan Borland $\mathrm{C}++$.

\section{Saran}

Untuk perbaikan pembuatan makalah di kemudian hari, saya berharap semua pihak, baik dosen maupun mahasiswa serta para pembaca lainnya yang membaca arsip "Bahasa Pemrograman C++ PC" ini, mempunyai ide-ide mengenai kelemahankelemahan yang terdapat dalam catatan ini. 
Sederhana Pada Bahasa Pem-

rogramanC++,(1),1-13. 2018

[10] Kurniawan,Imay.Implementasi Sistem De-

teksi Kemiripan Source Code C++

Menggunakan Analisis Leksial,(1),1-9.

2016

\section{REFERENSI}

[1] R.Hidayat.Belajar Dasar Algoritma Dan Pemrograman Dasar.(2017)

[2] Ricky.R.Saragih. Pemrograman dan Bahasa Pemrograman.Bahasa Pemrograman.18-19.2018.

[3] I.G.P. Sindhu. Dasar Sistem Komputer. Komputer. Medan:PT.RajaGrafindo Persada.(2021) Tersedia di E-Book.

[4] S.Hariyanto.Sistem Informasi Manajemen.80-81.(2017).

[5] A.Perdana Windarto dkk. Belajar Dasar Algoritma dan Pemrograman C++.(2016)

[6] Henry Febriana Harumy,T dkk.Belajar Dasar Algoritma dan Pemrograman. Yogyakarta:Deepublish.(2016) Tersedia dari books.google.com

[7] Sianipar, Rismon H.2015.Pemrograman C.Yogyakarta:Penerbit ANDI. Tersedia dari books.google.com,Gramedia, dan BukuKita.com

[8] Sinaga, Anita Sindar

RM,ST.,MTI.2019.Struktur Data dan Algoritma C++.Medan:CV.AA.Rizky.

Tersedia dari books .google.com,Gramedia, dan BukuKita.com

[9] O,L.Leonurdin Aziz. \& R,R.Alvin Adwitya. Meningkatkan Proses Pemahaman Operasi Perhitungan Bilangan Bulat Menggunakan Pseudocode Dan Program

[11] Dewi,Erawati.Media Pembelajaran Bahasa Pemrograman $C++, 7(1), 1-10.2016$

[12] Zahuri,Ilham.Bahasa Pemgrograman $C++, 1(1), 1-20.2015$

[13] Herling,Lonas Analisa Bahasa Pemrograman Gentee dengan Bahasa $C++, 1(1), 1-15.2015$

[14] Wirdasari.Bahasa Pemrograman C,8(1),1202016

[15] Jogiyanto \& Hartono,M..Konsep Dasar Pemrograman Bahasa C.Yogyakarta:Andi. 2019

[16] Fridayanthie,Eka \& Jimmy Charter.Object Oriented Programming $(O O P), 13(2), 1-9$. 2016 


\section{Akmal_Fakhlevi_PIK.docx}

ORIGINALITY REPORT

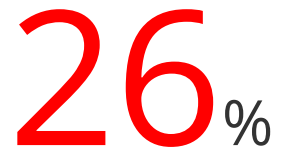

SIMILARITY INDEX
$26 \%$

INTERNET SOURCES
$1 \%$

PUBLICATIONS
$4 \%$

STUDENT PAPERS

PRIMARY SOURCES

1 hendrix-sudefri.blogspot.com

Internet Source

2 wWw.scribd.com

Internet Source

3 sayyidsani.blogspot.com

4 learn-tcode.blogspot.com

Internet Source

5 elib.unikom.ac.id

Internet Source

6 widiaafridani.wordpress.com Internet Source

7 muhamad4rif.simplesite.com 
11

Dogan Ibrahim. "Using LEDs, LCDs and GLCDs in Microcontroller Projects", Wiley, 2012 Publication

12 rizqipress.wordpress.com

13 ranaardila.blogspot.com

14 rutinitasinformatika.blogspot.com

Internet Source

15 www.coursehero.com

Internet Source

16 bamboszone.wordpress.com

17 docplayer.info

18 id.scribd.com

19 erreinasaifau.blogspot.com

lisvinasari.blogspot.com 
